\title{
The Contribution of Management Control to the Improvement of University Performance
}

\author{
Yasmine Benabdelkrim El Filali and Mohammed Saber Hassainate \\ Faculty of Legal, Economic and Social Sciences of Rabat-Agdal, \\ Laboratory of Management Sciences, Mohammed V University, Morocco
}

Correspondence should be addressed to: Yasmine Benabdelkrim El Filali; yasmine.elfilali@yahoo.fr

Received date: 23 November 2017; Accepted date: 03 May 2018; Publisher date: 09 July 2018.

Academic Editor: Chiraz Ben Salem Ben Gaied

Copyright (C) 2018. Yasmine Benabdelkrim El Filali and Mohammed Saber Hassainate. Distributed under Creative Commons CC-BY 4.0

\begin{abstract}
This article is devoted to the Moroccan public University. It is in the field of public higher education. It aims to identify the contribution of management control to the achievement of one of the main objectives of the Moroccan University, which is to improve performance while focusing on the use of the Balanced Scorecard (BSC) as a management tool and assistance to piloting.
\end{abstract}

Keywords: Management control, University, performance management, Balanced Scorecard (BSC).

\section{Introduction}

Become a source of progress, the importance of management control has been at length considered as a strategic value to all types of organizations. It is a discipline having as a goal the motivation of the responsible and their incentive to the execution of the activities that help to achieve the objectives fixed.
According to R. Anthony's (1965) most widespread definition: "Management control is the process by which managers ensure that resources are obtained and used efficiently and effectively for the goals of the organization"

It therefore represents a solution to a number of difficulties faced by companies for which the search for solutions is necessary. 
In a public logic, the purpose of management control is to insure that financial orthodoxy is respected in terms of the balance between revenues and public expenditure. Thereby, it essentially allows a conformity control to be carried out, taking the form of audit and inspection.

In the same logic, management control has the mission of creating economic rationality (a maximum of public goods and services with minimal expenditure and scarce resources).

In public establishments, the specificities of management control depend on the objectives set by the State to which it wishes to attain through the institution.

Without defined objectives, there can be no management control, since its practices and tools lead the manager to react, organize and decide according to a certain number of objectives.

However, it is difficult to define objectives in the public sector, mainly services (case of universities), including the translation of policy objectives into practical and measurable modalities.

This implies putting in place the adequate means to enable the establishment to achieve these objectives, while ensuring that they are taken into account when setting up a management control system.

Thus, management control should be reposed on the use of reliable, timely, detailed indicators adapted to the public logic, which is based not only on financial objectives but also on other public missions.

In Morocco, management control has developed strongly throughout the public sector, since it already meets the needs of budgetary control of guardianship in certain organizations.

It was on the basis of the Finance Act of 2002 that the Moroccan government introduced the principle of globalization of credits and contractualization in the budget, axed particularly on results and the search for performance and efficiency through A responsible practice of management methods and tools.

If we consider the University as a service producing system, its mode of governance undergoes both the constraint of the environment and that of the central power, while at the same time constantly seeking its own legitimacy.

The University is subject to the classic rules of public finance because it fulfills a public service mission of higher education. The charge of regulatory constraints as well as limitations of management control by its members generally weighs heavily on the system. This is why it is permissible to question the quality of budgetary methods in a dislocated environment known to be dependent on logic of "paying third party".

To achieve its performance, the University must emphasize its quality of teaching, the efficiency of its services, but also the optimization of its resources.

These requirements will only be assessed by the University through the effectiveness of a management control system.

In this context, management control appears to be a progressist element of a new practice of governance within universities, where the role of University presidents and administrators of the various councils will be decisive in the University's strategy, since it has a greater degree of management autonomy.

The purpose of this article is to identify the contribution of management control to the achievement of one of the main objectives of the Moroccan University, which is to improve performance while focusing on the use of the Balanced Scorecard as a management tool. 


\section{The Practice of Management Control in Public Establishments: Case of Universities}

\section{- What Is Management Control?}

Before defining management control, it seems useful to analyze the concept through its two terms: "control" and "management".

Control can be defined, according to $\mathrm{M}$. Laaribi (2004), as a 'technic', a procedure whose essential purpose is to assure that the results of the various activities are in line with the pre-established objectives of the organization.

By means of this definition, control consists of identifying the gaps between the planned objectives and the objectives achieved, analyzing and explaining the major differences in order to bring corrective measures to remedy the deviations observed.

Moreover, the word "management" refers to the way to use effectively the means (material, human, financial, information and technological) implemented to achieve the objectives set in advance.

Management control is used not only to control the management of an organization, but also to decline its strategy.

Considered as a management process, there is not (concretely) a single definition of management control, but a multitude of definitions that mark the evolutions traversed by this discipline since its appearance. Several approaches are proposed below.

The first definition of management control was proposed in 1965 by R. N. Anthony (considered as one of the founders of the discipline):

« Management control is the process by which managers ensure that resources are obtained and used efficiently and effectively for the goals of the organization » (R. N. Anthony, 1965)
A few years later, in 1988, Anthony rectified its definition, which began to doubt the effectiveness of this accounting vision of management control, and proposed a new definition different from that proposed in 1965:

«Management Control is the process by which managers influence other members of the organization to implement the organization's strategies » (R. N. Anthony, 1988)

According to the definition of R. Simons (1995): « Management control systems are the formal, information-based routines and procedures managers use to maintain or alter patterns in organizational activities »

According to this definition, management control is closely linked to the organization's information system, which can be either accounting, financial or operational, quantitative or qualitative, enabling managers to formulate a strategy and ensure its implementation.

In all definitions, the authors speak of organizations, which mean the applicability of management control to organizations that are not only private but also public.

The objective of management control is also identical, it is a matter of ensuring the implementation of the strategy of the organization, where the only difference lies in the way to achieve it.

The second definition of Anthony is probably closest to what has become the management control of our days; several common points are observed between the different definitions mentioned above:

- The management control is the guarantor of an economic logic, it must make it coherent with the strategy;

- Management control is addressed to responsibles, namely the persons who, according to Anthony, must achieve goals through the action of others; 
- It is a tool for decision-making, efficacy and efficiency; It is a tool to help the regularity of the information system in the organization.

Management control therefore enables managers to understand the future and act accordingly.

- Context for setting up a management control system within a public establishment: case of universities

Today, the Moroccan public administration is crossing a decisive step in its life cycle, characterized by a number of challenges that it is bound to lift up and which are dictated by the multiple evolutions, and rapid, of its environment.

In this context, the Moroccan public administration has been engaged for several years in a modernization program aimed at lightening administrative structures, simplifying procedures, improving performance and enhancing the quality of services provided.

In order to prepare for this major project of structural and organizational change, managers tend to be equipped with modern management systems, helping them to control the mechanisms of public management.

It is in this perspective that the study of the contribution of management control to organizational performance within the Moroccan public sector is of major interest. Indeed, management control is at the heart of the performance monitoring process and contributes to its improvement. It focuses on the essential points of daily life of the units: the resources allocated, the activities realized and the services rendered. It extends to all the entities and is concretized by exchanges of directives, dashboards and reports between the various hierarchical levels (of responsibility).

Indeed, in the face of imperatives such as profit making, achieving better for shareholder returns and increasing market share, managers in the private sector use tools such as management control to reduce costs, realize profit margins and pilot performance. But when it comes to the public sector, the notion of profit is generally absent, it is generally not subject to competition.

Also, the specificity of management control in the public sector is that it concerns service activities, which are different from the industrial activities for which management control was originally designed.

In this particular context, management control nevertheless allows to introduce the culture of performance by the definition of objectives to be attained and the measurement of achievements.

If we consider the University as a service producing system, its mode of governance is submitted to profound mutations registering in the current of New Public Management (NPM).

Assimilated to a dynamic of managerialization of public organizations, the latter tries to introduce the concept of performance by promoting the deployment of management control tools. Thenceforth, the applicability of performance measures used by private sector organizations in public organizations appears to be a great stake for the NPM: the private sector is the benchmark; the NPM incorporates the values traditionally identified in these organizations to promote efficiency and efficacy of public activities.

In the framework of this new public management, the recent reform of higher education through Law 01-00 related to the organization of Moroccan higher education, has allowed reinforcing the pedagogical, administrative and financial autonomy of universities, henceforth entrusted to presidents of universities.

Such autonomy accorded by public authorities requires universities to establish their own strategic plans and to be accountable for the results achieved. 
In the face of this imperative, the University must not only adopt new management methods based on performance management, but also set up more effective monitoring mechanisms, which can only inform decision-making and enable to judge the opportunity of decisions.

In addition, these management control services should not only be responsible for the financial aspects of University management, but should also cover human resources dimensions, which are major levers for strengthening the establishment's governance.

\section{Role of Management Control in the Improvement and Monitoring of University Performance}

\section{- Management Control and University Performance: What Interaction?}

Performance is an encompassing and integrating concept, therefore, difficult to define precisely. According to the majority of the literature consulted, there are several conceptually acceptable but distinct definitions of performance according to the field concerned and the context of use. As Saucier (1995, p 16) points out, the concept of performance must, therefore, also be specified whenever one wishes to use it.

In management, the term performance is defined as the combination of efficacy (result obtained with respect to the objective sought) and efficiency (result obtained compared to the means implemented).

Performance therefore requires an interdependent global vision of all internal and external parameters, quantitative and qualitative, technical and human, physical and financial management.

Being defined as the set of procedures representing the whole functioning of an organization, management control can have a very important contribution to the piloting of University performance by fulfilling two roles: steering of efficacy and efficiency.

- Help to pilot the efficacy: ie to manage key success factors through a set of strategic decisions and actions.

- Help to pilot the efficiency: that is, to manage the operational means to achieve the set objectives, thus mastering the key factors of financial equilibrium.

Management control must be interacting with the objectives and strategies of the University. Techniques for preparing, coordinating and monitoring activity should be articulated from the overall objectives and strategies for the University and should be used to measure their efficiency and efficacy.

Thus, the management control takes place before, during and after the action.

This approach to performance management therefore allows to reinforce the autonomy and responsibility of University managers who are committed to results in terms of clearly defined objectives and means and to meet the requirement efficacy of the results and efficiency of the resources committed to the implementation of public action.

\section{- Balanced Scorecard as the main tool for managing and monitoring University performance}

In recent years, organizations' performance measurement systems have focused on traditional management control data: calculation of internal and external costs, productivity ratios, generalist financial ratios, etc., without taking into account the environment in which the organization evolves.

Faced with these purely financial indicators, the strategy's management remains limited, since performance is no longer linked only to cost calculations, but also to its environment and intangible capital, which constitute the element of modern management renewal. 
The need to have a tool that takes into account financial and non-financial performance indicators has allowed managers to use dashboard templates, which are deemed to be more comprehensive.

As quoted by Löning et al. (2003, p 158), short-term measures will have to be replaced by multiple non-financial indicators that are better targets and have a better predictive value in terms of the organization's long-term profitability goals.

Thus, it's in the nineties that Kaplan and Norton (1992) developed the Balanced Scorecard, which is called a strategic / prospective / balanced scorecard, which incorporates indicators of past performance and the determinants of future performance. The authors present it as follows:

“...Balanced Scorecard (BSC) is a new framework for integrating strategic indicators: in addition to financial indicators of past performance, it proposes indicators of future performance ... BSC declines mission and strategy as objectives, there are based on four axes: the financial axis, that of the performances towards the customers, that of the internal processes and that of the organizational learning" (Kaplan and Norton, 1996, p 31).

The original model of the BSC describes the mission and the strategy in terms of objectives and measures, allowing describing the overall performance of an organization based on four axes of performance, as follows:

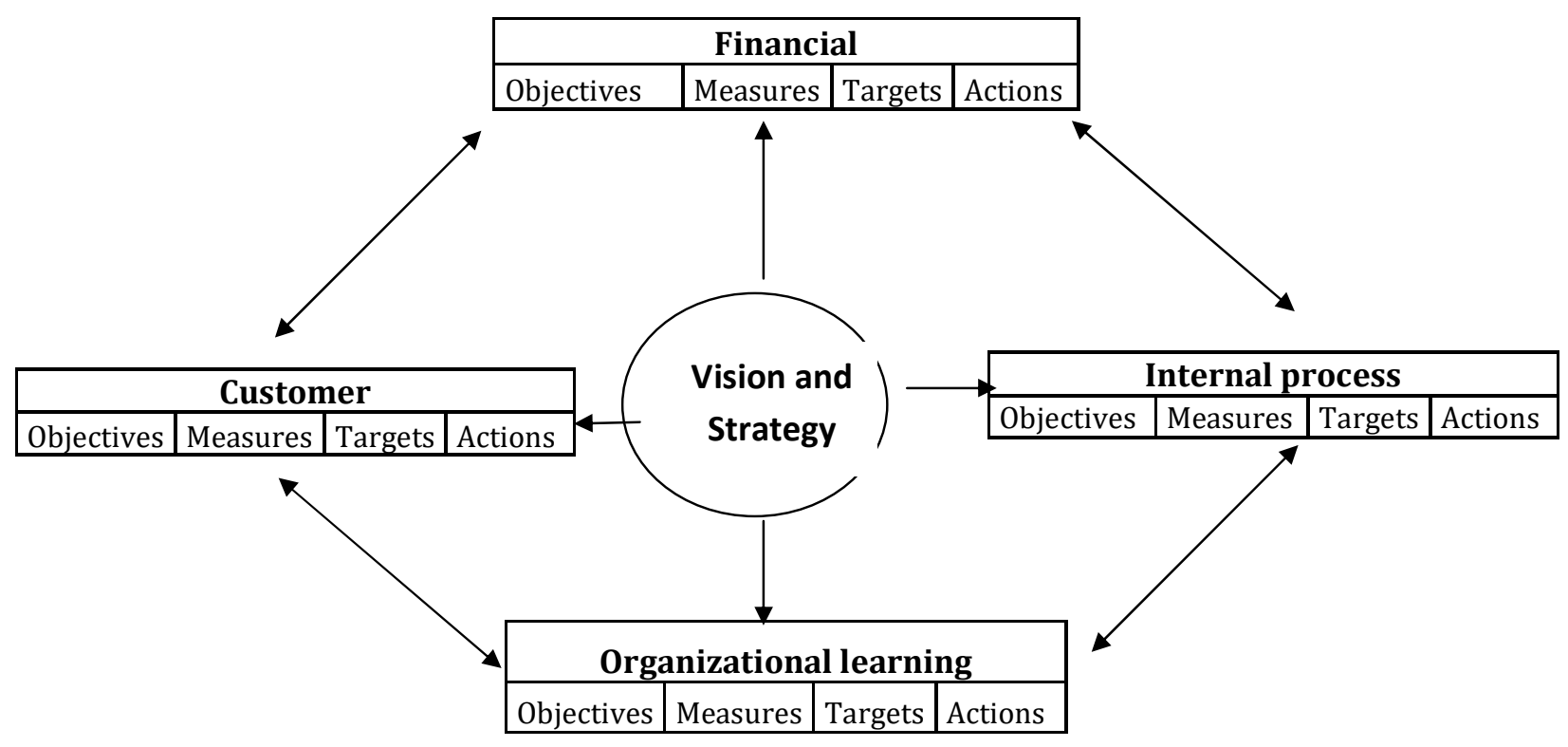

Fig 1: Architecture of the Balanced Scorecard according to Kaplan and Norton

- Customer: How to measure customer satisfaction (students, professors, administrators, employers, parents...) and their expectations?

- Financial: How are we perceived by our financers?
- Learning and growth: How to optimize the transfer of knowledge and improve the value of the University?

- Internal process: What internal processes do we need to excel in order to succeed? 
Thus, these four axes make it possible to establish a causal link between the strategy and the performance indicators and to establish a balance between the objectives set, the results to be achieved and the determinants of these results (Kaplan and Norton, 1998).

To achieve its performance, the University must emphasize its quality of teaching, the efficiency of its services, but also the optimization of its resources.

These requirements will be assessed by the University only through the effectiveness of a management tool that measures both financial and non-financial performance namely: the Balanced Scorecard, where many institutions have borrowed the same way of using this tool, such as the United States (University of California, University of Vermont, University of Akron, ...), Canada (Carleton University, ...), or Australia (Deakin University, Bond University of
Edinburgh, University of Edinburgh, Glasgow Caledonian University, etc.).

In this context, the Balanced Scorecard appears to be a progressive element of a new practice of governance within universities where the role of University presidents and administrators of the various councils will be decisive in the University's strategy, because it has strengthened management autonomy.

The usefulness of setting up the Balanced Scorecard available to University presidents serves mainly to identify the situation and the evolution of the University through a limited number of objectives and Indicators, supplemented by comments and corrective measures, structured in four axes of performance improvement.

Below is an example of a Balanced Scorecard for a Moroccan university, each project must be associated with indicators:

Table 1: Global example of a Balanced Scorecard for a university

\begin{tabular}{|c|c|c|c|}
\hline \multicolumn{2}{|c|}{ Customer } & \multicolumn{2}{|c|}{ Financial } \\
\hline Goal & Indicator & Goal & Indicator \\
\hline $\begin{array}{l}\text { Focus on the student's } \\
\text { fulfillment for his success }\end{array}$ & $\begin{array}{l}\text { Satisfaction rate of } \\
\text { students about the } \\
\text { university campus and } \\
\text { catering }\end{array}$ & $\begin{array}{l}\text { Diversify the } \\
\text { University's sources of } \\
\text { funding }\end{array}$ & Rate of own resources \\
\hline \multicolumn{2}{|c|}{ Internal Process } & \multicolumn{2}{|c|}{ Learning and growth } \\
\hline Goal & Indicator & Goal & Indicator \\
\hline $\begin{array}{l}\text { Open up to his socio-cultural } \\
\text { environment }\end{array}$ & Socio-cultural events & $\begin{array}{l}\text { Establish managerial } \\
\text { culture in governance }\end{array}$ & $\begin{array}{l}\text { Existence of a quality } \\
\text { unit within the } \\
\text { university presidency }\end{array}$ \\
\hline
\end{tabular}

For the university, like private and public organizations, the purpose is not good financial performance but customer satisfaction.

The customers of the university are multiple. According to Heldenbergh and Sénéchal (2011), the perception of the "customer" axis can take several forms:
- Society: "represents the widest beneficiary who benefits from the different missions undertaken by the university";

- Students: considering training as the main mission of the university, it is then the students who represent the direct beneficiaries; 
- The job market, the parents who finance the studies ...: the perception of the customer can indeed be extended to many other stakeholders;

- The researchers: "have many expectations: need an intellectually stimulating work environment within the research teams..."

- The research sponsors: "expect exploitable results that allow them to create value quickly enough".

Faced with this polymorphism, the two authors note that it is judicious to transform the axis "customer" of the BSC in axis "stakeholders" and that it is in any case necessary to exclude 'the normative approach of the customer traditionally proposed by the BSC'.

The usefulness of its implementation will enable the President and his team to:

- Ensure that the results are in line with the objectives set;
- Use corrective actions on means and activities (eg indicators that would no longer be valid);

- To adapt the objectives, targets and trajectories in agreement with the stakeholders.

- Provide the University with a real recognition through the valorization of its activities with the regional, national and international actors

- Identify actions and measures, organizational, functional and budgetary;

- Perform comparisons and benchmarking;

- Improve internal and external communication (through the predefined objectives, each collaborator has an important role in the success and performance of the University).

The Balanced Scorecard is therefore a compass to guide the University, which can be adjusted, modified or adapted according to changes in the environment (examples: structure, technology, legislation, etc.).

Table 2: Detailed example of a Balanced Scorecard

\begin{tabular}{|c|c|c|c|c|c|c|c|}
\hline \multirow[b]{2}{*}{ Axis } & \multirow[b]{2}{*}{ Objectives } & \multirow[b]{2}{*}{ Indicator } & \multirow[b]{2}{*}{ Calculation } & \multirow[b]{2}{*}{ Periodicity } & \multicolumn{2}{|c|}{ Value } & \multirow[b]{2}{*}{ Initiatives } \\
\hline & & & & & Real & Target & \\
\hline \multicolumn{8}{|l|}{ Stakeholders } \\
\hline \multicolumn{8}{|l|}{ Financial } \\
\hline \multicolumn{8}{|l|}{$\begin{array}{l}\text { Internal } \\
\text { process }\end{array}$} \\
\hline $\begin{array}{l}\text { Learning and } \\
\text { growth }\end{array}$ & & & & & & & \\
\hline
\end{tabular}


This article is only the beginning of a large research project on the application of a Balanced Scorecard (BSC) in Moroccan universities, a topic not yet exploited in Morocco.

Thus, a pilot study was conducted at a Moroccan university ranked first nationwide, the results of which will shed light on the following problematic:

How can the implementation of the Balanced Scorecard within the university ensure a good deployment of the strategy and ensure an effective implementation of a performance management tool?

The methodology implemented in the following of this research is quantitative, to which a questionnaire survey was conducted at this university, to test the following hypotheses:
H1: University performance is linked to the knowledge of the strategy by the administrative staff

H2: University performance is related to the degree of communication between the University and its stakeholders.

H3: University performance is measured by financial and nonfinancial indicators

H4: University managers are motivated to adopt the concept of the Balanced Scorecard

For this purpose, we chose from among 174 managers from different departments of the University, a sample of 120 people randomly drawn using the probabilistic sampling method, to which our questionnaire was sent.

Table 3: Summary of the sending and the return of the questionnaire

\begin{tabular}{|l|c|c|c|c|c|}
\hline & Electronically & $\begin{array}{c}\text { Paper } \\
\text { support }\end{array}$ & $\begin{array}{c}\text { Face to } \\
\text { face }\end{array}$ & Total & $\%$ \\
\hline Number of questionnaires sent & 38 & 80 & 2 & 120 & $100 \%$ \\
\hline Number of complete responses & 27 & 31 & 2 & 60 & $50 \%$ \\
\hline $\begin{array}{l}\text { Number of incomplete } \\
\text { responses }\end{array}$ & - & 12 & - & 12 & $10 \%$ \\
\hline $\begin{array}{l}\text { Number of empty } \\
\text { questionnaires }\end{array}$ & 11 & 37 & - & & $40 \%$ \\
\hline
\end{tabular}

Given the number of questionnaires administered, the response rate equals $60 \%$. We finally kept 60 complete and workable answers, representing a real response rate of $50 \%$.

The processing of the collected data will be done through various statistical analyzes across the software SPSS:

- Univariate analysis, to study the distribution of a single variable;
- Bivariate analysis, to study the distribution between two variables and their possible link (through the Chi-square test);

- Multivariate analysis, to study the distribution of several variables, through the Principal Component Analysis (PCA) method, considered as one of the most used methods in the analysis of quantitative variables. 
An explanatory analysis will test the hypotheses of the model and measure its explanatory scope in its entirety, and will be the subject of a future publication of an article dealing with the main results of our research.

\section{Conclusion}

In a Moroccan context marked by the will to establish good public service governance and the search for the performance of the higher education system, namely the University, it is now called to account for its efficacy and its efficiency in the use of public funds and the accomplishment of the missions assigned to it, taking into account the autonomy granted to it by the public authorities.

Faced with these imperatives, management control intervenes in the steering of universities, helps to analyze deviations, to establish recommendations, allows decision-makers to revise their decisions and actions according to the information provided, and to encourage Operational staff work in the direction defined by the strategy.

Thus, in a public body, such as the University, where financial and nonfinancial performance appears to be important, the balanced scorecard could be an ideal instrument for steering the overall performance of the University.

From the perspective of an analysis of a Moroccan university, the BSC built from a set of indicators, could be adopted as a standardized model and as a reporting tool for decision-makers and stakeholders. It could be an appropriate framework to measure the multidimensional character of the university's performance, whose main activity is the production of knowledge and know-how.

Moreover, it represents a modern and integrated management tool, particularly likely to be appreciated by the university presidency, which sometimes does not manage to ensure a follow-up in the university management.
Future research could therefore examine how factors such as strategy and the external environment determine the effectiveness of a BSC within a Moroccan university, and test how it will react to the new concept presented.

\section{References}

1. ANTHONY R. N. (1965) 'Planning and Control Systems: a Framework for Analysis,' Harvard University, First Edition. 2. ANTHONY R. N. (1988) 'The management control function,' Harvard University Press, Boston.

3. KAPLAN R., NORTON D. (1992) 'The Balanced Scorecard. Measures That Drive Performances,' Harvard Business Review, pp. 71-79.

4. KAPLAN R., NORTON D. (1996) 'The Balanced Scorecard: Translating Strategy into Action,' Harvard Business Review, 329 p.

5. KAPLAN R., NORTON D. (1996) 'Using the Balanced Scorecard as a Strategic Management System', Harvard Business Review, 329 p.

6. Kaplan R., Norton D. (1998), Le Tableau de Bord Prospectif, Les Editions d'Organisation, Paris.

7. LAARIBI M., (2004) 'Le contrôle de gestion dans les entreprises marocaines, concepts et pratiques', 2ème édition, Facogem.

8. Law No. 01-00 related to the organization of higher education in Morocco.

9. LÖNING, H. et al. (2003) 'Le contrôle de gestion: organisation et mise en œuvre'. Dunod, 2 ème Ed. Paris, 277 p.

10.SAUCIER A. (1995) 'Les indicateurs et la gestion par résultats', Gouvernement du Québec, Ministère de la Santé et des Services sociaux, Collection méthodologie et instrumentation, No. 8, 33 p.

11.SENECHAL O., HELDENBEGH A. (2011), 'Adaptation du Balanced Scorecard en soutien aux démarches qualité et au pilotage d'universités'. Colloque international Performances et institutions : de l'efficience au pluralisme ? Université de Reims Champagne-Ardenne. Reims.

12.SIMONS R., (1995) 'Levers of control: How managers use innovative control systems to drive strategic renewal,' 
Journal of North African Research in Business

Strategic Management Journal, vol 15, Harvard Business School Press, pp.169189.

\section{Notes}

Globalization of credits: Consists of granting organizers and under-organizers

more flexibility in the use of the credits available to them, in return for their personal accountability for the achievement of the objectives assigned to them and the obligation to account for these results. 